\title{
ANALISA DAN PERANCANGAN SISTEM INFORMASI JADWAL PERKULIAHAN (SIJADKUL) MENGGUNAKAN WEB PADA STMIK ROSMA
}

\author{
${ }^{1}$ Mohamad Jejen Supraja, S.Kom., ${ }^{2}$ Dudi Awalludin, M.Kom., \\ Email : ${ }^{1}$ mohamad.jejen@yahoo.com, ${ }^{2}$ dudi@rosma.ac.id
}

\begin{abstract}
Abstrak
Perkembangan teknologi informasi dan komunikasi memberikan sesuatu yang bermanfaat berupa kemudahan dalam informasi-informasi yang dibutuhkan. Suatu perusahaan atau instansi perlu menerapkan sistem informasi dalam kegiatan mereka berjalan dengan baik dan sesuai keinginan yang semestinya. Pengaturan jadwal perkuliahan adalah merupakan suatu kegiatan yang dilakukan oleh BAAK yang selama ini dilakukan secara manual, dan distribusi jadwal perkuliahan kepada mahasiswa dan dosen pun dirasa kurang efektif. Sistem Informasi Jadwal Perkuliahan menggunakan web di harapkan mampu dalam pembuatan jadwal dan distribusi jadwal ke dosen dan mahasiswa Tahapan pengembangan peneilitian ini dengan menggunakan metode Software Development Life Cycle (SDLC) yaitu tahap analisa, desain dan implentasi. Tools yang digunakan pada penelitian ini adalah Notepad++ dan MySQL sebagai databasenya. Hasil analisis ini diharapkan dapat membantu bagian Akademik (BAAK) dalam membuat jadwal kuliah.
\end{abstract}

Kata Kunci :Sistem Informasi Jadwal Kuliah, Web, My SQL

\section{Abstract}

The development of information and communication technologies provide something useful such as the ease of information needed. A company or agency needs to implement information systems in their activity goes well and according to proper wishes. Setting the schedule of lectures is an activity undertaken by BAAK has been done manually, and distribution schedule of lectures to students and faculty was deemed less effective. Class Schedule Information System using the web in the hope capable of scheduling and distribution to faculty and student schedule. Stages of development of this research by using Software Development Life Cycle (SDLC) is a stage of analysis, design and implentasi. Tools used in this research is Notepad ++ and MySQL as the database. Results of this analysis is expected to help part Academic (BAAK) to create class schedules.

Keywords: Class Schedule, Information Systems, Web, MySQL

Jurnal Interkom: Jurnal Publikasi Ilmiah Bidang Teknologi Informasi dan Komunikasi

Volume 15 Nomor 01 Bulan April - Tahun 2020 


\section{Pendahuluan}

Perkembangan ilmu pengetahuan dan teknologi sekarang ini mengalami kemajuan yang sangat pesat terutama teknologi yang berbasis komputer. Hampir disemua bidang telah menggunakan komputer sebagai alat bantu untuk mendukung evaluasi, analisis serta efisiensi dan efektifitas dalam proses pengambilan keputusan dan kebijaksanaan. Dalam mengolah informasi, diperlukan suatu alat elektronik yaitu berupa komputer yang dapat mengolah data secara cepat dan dapat menghasilkan informasi terbaik yang kita butuhkan, yang sanggup mengatasi segala kelemahan dan kekurangan dalam sistem informasi yang mengandalkan tenaga manusia.

Sistem terkomputansi pada saat ini sudah banyak di terapkan di bidang pendidikan, baik formal dan informal. STMIK ROSMA sebagai pelopor IT di Kabupaten Karawang tentunya mempunyai visi dan misi yang jelas dalam meningkatkan mutu IT di Karawang. Untuk sistem jadwal perkuliahan dan jam mengajar dosen masih belum bisa diakses secara online dan mahasiswa pun harus datang ke kampus untuk melihat jadwal kuliah.

Sistem tersebut perlu dioptimalkan maka dibutuhkan sebuah sistem yang terkomputansi. Maka pergantian dari sistem yang lama ke sistem yang baru diharapkan informasi lebih cepat dan akurat. Berdasarkan hal tersebut diatas, untuk dapat menyusun dan merancang suatu sistem yang terintegrasi antar fungsi-fungsi yang terkait dalam kampus, yang diharapkan nantinya merupakan suatu solusi terhadap permasalahan yang terjadi.

Penelitian terdahulu yang membahas tentang sistem informasi penjadwalan perkuliahan adalah sebagai berikut :

1. Penelitian ini merupakan penelitian sebuah skripsi Membahas mengenai penjadwalan perkuliahan dari mulai persiapan matakuliah yang disajikan, pengelolaan kesediaan mengajar dosen, hingga laporan kinerja dosen dalam mengajar. Model pengembangan Sistem Informasi menggunakan Model Rapid Application (Fachrurozi, 2011).

2. Penelitian ini berjudul Sistem Informasi Jadwal Perkuliahan dengan Metode Sistem Pakar, mengupas tentang sistem informasi perkuliahan dapat meningkatkan pelayanan dalam pengaturan dan penjadwalan ruang kuliah, meminimalisir terjadinya tabrakan jadwal kuliah dan tabrakan dalam penggunaan ruang kuliah (Nurwarsito, 2009).

3. Analisis Dan Perancangan Sistem Informasi Penjadwalan Kuliah Pada STIE Muhammadiyah Pekalongan merupakan judul dari penelitian yang membahas tentang mempercepat pembuatan penjadwalan perkuliahan dan pelaksanaan perkuliahan akan lebih lancar. Pebangunan sistem informasi dengan menggunakan Visual Basic 6.0 dengan database Access (Maria, 2010).

4. Penelitian ini dilakukan untuk mempercepat penyusunan jadwal perkuliahan dengan menggunakan teknologi SMS Gateway dan berbasis web, dengan judul penelitian Analisis Dan Perancangan Sistem Informasi Penjadwalan Kuliah Pada STIE Muhammadiyah Pekalongan (Darmadji, 2008).

5. Penelitian membahas tentang kesulitan manusia dalam menyusunan jadwal kuliah dikarenakan dalam pembuatan jadwal perkuliahan banyak batasan yang mengakibatkan sering terjadinya kesalahan yang tak terhindarkan, sehingga dalam pembuatan jadwal perkuliahan menggunakan teknologi komputasi untuk memudahkan petugas dalam pembuatan jadwal kuliah. Graph Colouring digunakan untuk pengecekan bentrok sampai ke tingkat mahasiswa yang merupakan bahan kajian pada penelitian ini(Wibisono et al., 2009).

Penelitian ini model pengembangan sistem informasi menggunakan model Waterfall yang memiliki enam (6) tahapan yang terdiri atas : analisis, perancangan, coding, pengujian, dan perawatan. Tahapan yang dihunakan pada model Waterfall hanya pada tahapan analisis dan perancangan.

\section{Tinjauan Pustaka}

"Sistem adalah sekumpulan hal atau kegiatan atau elemen atau subsistem yang saling bekerja sama atau yang dihubungkan dengan caracara tertentu sehingga membentuk satu kesatuan untuk melaksanakan suatu fungsi guna mencapai suatu tujuan, (Sutanta, 2011:4)." 
Informasi merupakan data yang telah diolah sehingga menjadi suatu bentuk yang penting yang berguna bagi penerimanya dan mempunyai kegunaan sebagai dasar dalam pengambilan keputusan yang dapat dirasakan akibatnya secara langsung atau secara tidak langsung dimasa yang akan datang, (Hartono, 2013:66)."

Sistem Informasi menurut O’Brian (2005) merupakan kombinasi teratur dari orang-orang, perangkat keras (hardware), perangkat lunak (software), jaringan komunikasi dan sumber daya data yang mengumpulkan, mengubah dan menyebarkan informasi dalam sebuah organisasi, (Yaqub, 2012:17)."

Kualitas dari informasi tergantung dari tiga hal yaitu accurate, timeliness, dan relevance, (Jogiyanto, 2010:9)."

1. Relevan (relevance), berarti informasi tersebut mempunyai manfaat untuk pemakaianya dan relevansi informasi untuk tiap-tiap orang akan berbeda-beda

2. Tepat waktu (timeliness), berarti informasi tersebut datang pada penerima tidak boleh terlambat. Informasi yang sudah usang tidak akan mempunyai nilai lagi, karena informasi merupakan landasan di dalam pengambilan keputusan.

3. Akurat (accurancy), berarti informasi harus bebas dari kesalahan-kesalahan dan tidak menyesatkan. Akurat juga berarti informasi harus jelas mencerminkan maksudnya. Informasi harus akurat karena dari sumber informasi sampai ke penerima informasi kemungkinan banyak terjadi ganguan (noise) yang dapat merusak informasi.

Berikut ini gambar pilar kualitas informasi.

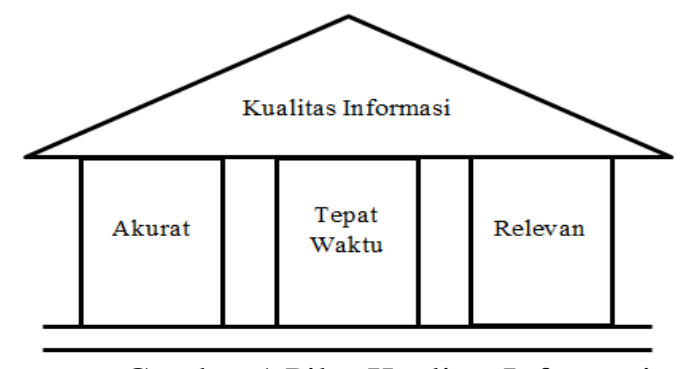

Gambar 1 Pilar Kualitas Informasi

Systems Development Life Cycle merupakan siklus hidup pengembangan sistem. Dalam rekayasa sistem dan rekayasa perangkat lunak, SDLC berupa suatu proses pembuatan dan pengubahan sistem serta model dan metodelogi yang digunakan untuk mengembangkan sistem tersebut, (Hartono, 2013:129)."

Fungsi SDLC untuk menggambarkan tahapan-tahapan utama dan langkah-langkah dari setiap tahapan $S D L C$ sebagai berikut :

1. Perencanaan
a. Mengidentifikasikan nilai bisnis
b. Analisis kelayakan
c. Mengatur staff
d. Mengontrol dan mengarahkan projek

2. Analisis
a. Analisis masalah \& mencari informasi yang terkait
b. Menentukan model proses
c. Menentukan model data

3. Perancangan
a. Perancangan proses secara fisik
b. Perancangan arsitektur sistem
c. Perancangan interface
d. Perancangan basis data dan berkas
e. Perancangan program

4. Coding
a. Membuat coding sesuai kebutuhan sistem
b. Implementasikan hasil desain ke kode

5. Pengujian
a. Menguji program apakah sudah benar atau belum
b. Menguji setiap menu pada program

6. Perawatan
a. Menangani perangkat lunak yang sudah selesai
b. Menjaga program agar terhindar dari gangguan yang menyebabkan kerusakan
Model Waterfall adalah tahapan utama yang langsung mencerminkan dasar pembangunan kegiatan. Disebut dengan waterfall karena tahap demi tahap yang dilalui harus menunggu selesainya tahap sebelumnya dan berjalan berurutan, (Sommerville, 2011:30-31)."
Tahapan pada model waterfall dapat dilihat pada gambar berikut : 


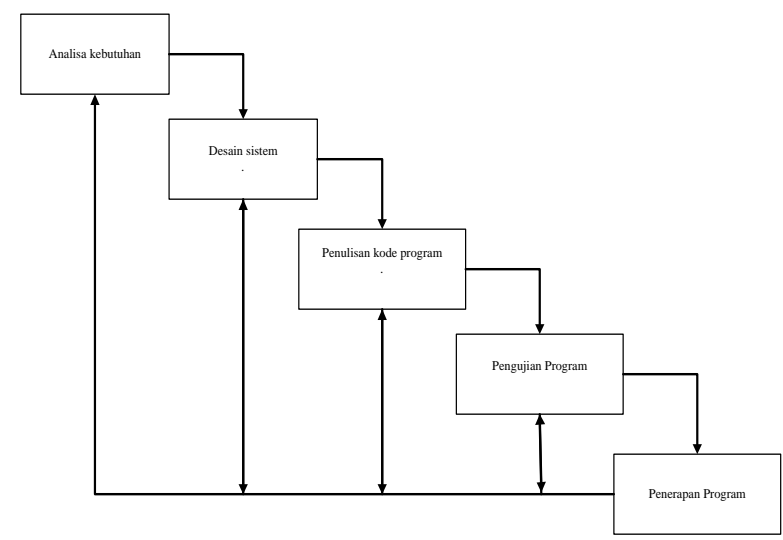

Gambar 2 SDLC Waterfall

Data Flow Diagram (DFD) adalah suatu diagram yang menggunakan notasi-notasi untuk menggambarkan arus dari data sistem, yang penggunaanya sangat membantu untuk memahami sistem logika, terstruktur dan jelas (Hartono, 2013:56)."

Entity Relationship Diagram (ERD) merupakan teknik yang digunakan untuk memodelkan kebutuhan data dari suatu organisasi, biasanya oleh System Analys dalam tahap analisis persyaratan proyek pengembangan sistem. Sementara seolah-olah teknik digram atau alat peraga memberikan dasar untuk desain database relasional yang mendasari sistem informasi yang dikembangkan. ERD bersama-sama dengan detail pendukung merupakan model data yang pada gilirannya digunakan sebagai spesifikasi untuk database, (Hartono, 2013:178)."

Pengertian jadwal menurut kamus besar bahasa Indonesia (1988) adalah pembagian waktu berdasarkan rencana pengaturan urutan kerja, daftar atau tabel kegiatan atau rencana kegiatan dengan pembagian waktu pelaksanaan yang terperinci. Sedangkan pengertian penjadwalan adalah proses, cara, perbuatan menjadwalkan atau memasukkan ke dalam jadwal.

Kuliah mempunyai arti pelajaran yang di berikan atau ceramah. Namun pada umumnya kata kuliah sering di kaitkan pada perguruan tinggi atau pendidikan tinggi yang sering di artikan sebagai proses pembelajaran atau proses belajar.

\section{Metode Penelitian}

Penelitian ini menggunakan metode penelitian model SDLC yang akan digunakan yaitu. Model yang terkenal dan banyak digunakan model klasik yang biasa disebut dengan model waterfall. Disebut dengan waterfall karena tahap demi tahap yang dilalui harus menunggu selesainya tahap sebelumnya dan berjalan berurutan, (Summerville, 2011:31).

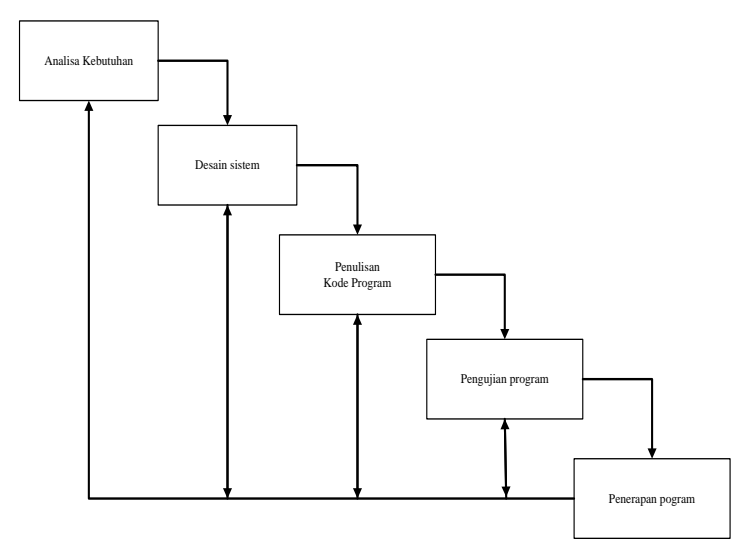

Gambar 3 SDLC Waterfall

Gambar 1 SDLC waterfall tersebut pada kelima tahapan penulis melakukan 2 tahapan awal yaitu Analisa Kebutuhan Sistem dengan Desain Sistem. Berikut adalah penjelasan detail dari kedua tahap tersebut, yaitu :

\section{Analisa Kebutuhan}

Pada tahap ini mengumpulkan data dan kebutuhan system kemudian dilakukan analisis sistem yang berjalan dengan menggunakan Flow of Document. Metode pengumpulan data menggunakan :

a. Observasi

Pada sistem observasi ini pengumpulan data dilakukan dengan cara pengamatan dan pencatatan langsung ke lapangan di STMIK ROSMA.

b. Studi Kepustakaan

Studi kepustakaan yang penulis ambil meliputi buku-buku dan literatur-literatur yang berhubungan langsung dengan sistem pendukung keputusan. Media lain berupa internet yang berhubungan dengan sistem informasi.

c. Wawancara

Guna mendapatkan informasi akademik yang berkaitan dengan penulisan skripsi ini, penulis langsung mewawancara staff BAAK STMIK ROSMA.

\section{Desain Sistem}

Proses ini digunakan untuk mengubah kebutuhan-kebutuhan diatas menjadi 
representasi ke dalam bentuk "blueprint" software sebelum coding dimulai. Desain harus dapat mengimplementasikan, pada tahapan ini menggunkan Bagan Alir Sistem (System Flow Chart), Diagram Arus Data (Data Flow Diagram), Kamus Data (data dictionary), ERD (Entitas Relation Diagram).

\section{Hasil Dan Pembahasan}

Analisis prosedur pada sistem yang sedang berjalan bertujuan untuk mengetahui lebih jelas bagaimana cara kerja sistem tersebut, sehingga kelebihan dan kekurangan sistem dapat diketahui.

Penjadwalan kuliah di buat oleh BAAK untuk memulai perkuliahan di tiap semester.

Dibawah ini adalah prosedur dalam pembangunan jadwal perkuliahan :

\section{Waket 1 :}

a. Memberikan distribusi matakuliah yang telah disahkan ke BAAK.

b. Menerima draft jadwal perkuliahan dari BAAK.

c. Menandatangani draft jadwal perkuliahan apabila sudah oke, apabila masih ada kesalahan mengembalikan lagi ke BAAK.

d. Memberikan jadwal perkuliahan yang telah di tanda tangan ke BAAK.

\section{Dosen :}

a. Menerima surat kesanggupan mengajar dari BAAK.

b. Mengisi surat kesanggupan mengajar.

c. Menyerahkan surat kesanggupan mengajar yang telah di isi tersebut ke BAAK.

d. Menerima surat jadwal perkuliahan dari BAAK.

3. Bag. Umum :

Memberikan data ruangan ke BAAK.

4. BAAK :

a. Memberi dan menerima surat kesanggupan dosen mengajar dari tiap dosen.

b. Menerima distribusi matakuliah dari Waket 1

c. Menerima data ruangan dari Bag. Umum

d. Membuat draf jadwal perkuliahan dan memberikan ke Waket 1 untuk di periksa.

e. Menerima jadwal perkuliahan yang telah di setujui oleh Waket 1 dan memperbaiki jadwal perkuliahan apabila masih ada kesalahan. f. Menandatangani jadwal yang telah di tanda tangan oleh Waket I

g. Membuat surat jadwal pekuliahan untuk dosen, kemudian memberikannya kepada dosen.

h. Menempelkan jadwal perkuliahan di mading kampus.

\section{Mahasiswa :}

Melihat jadwal yang telah di buat oleh BAAK di mading.

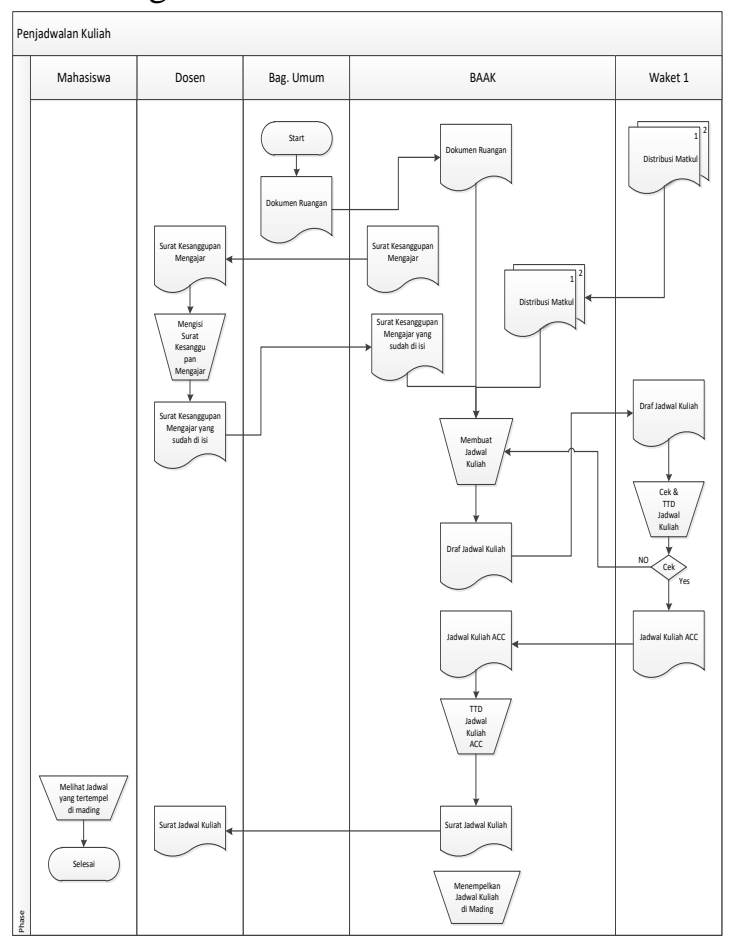

Gambar 4 Alur Dokumen Jadwal Perkuliahan

Setelah menganalisa sistem yang sedang berjalan, maka didapat permasalahan yang ditemui pada sistem informasi jadwal perkuliahan di STMIK Rosma. Diantaranya adalah sebagai berikut: tidak fleksibelnya mahasiswa dalam melihat jadwal perkuliahan sehingga mereka harus datang langsung ke kampus untuk melihat jadwal perkuliahan

Berdasarkan dengan permasalahan yang ditemui penulis, maka penulis mencoba memecahkan masalah tersebut yaitu dengan cara:

1. Dibuatnya Sistem Informasi Jadwal Perkuliahan (SIJadKul) berbasis web agar mudah untuk diakses oleh dosen dan mahasiswa.

2. Dengan adanya SIJadKul dosen dan mahasiswa bisa mengakses jadwal perkuliahan dimana saja. 
3. Akses jadwal lebih cepat atau dapat di akses secara langsung.

Analisis Sistem adalah penguraian dari suatu sistem informasi yang utuh kedalam bagian komponennya dengan tujuan untuk mendefinisikan dan mengevaluasi permasalahan serta hambatan yang terjadi sehingga dapat diusulkan perbaikannya.

Analisis prosedur ini dilakukan untuk mengetahui Sistem Informasi Jadwal Perkuliah di STMIK Rosma. Dalam hal ini dapat dilihat berupa alur-alur serta arah sistem yang berjalan yakni :

\section{Waket I :}

a. Memberikan Distribusi Matakuliah dan Dosen (DMD) yang telah disahkan ke BAAK.

b. Menyetujui jadwal perkuliahan yang telah di buat BAAK melalui SIJadKul.

2. Dosen :
a. Mengakses Formulir Kesanggupan Mengajar (FKM) dari SIJadKul melalui Link yang telah diberikan oleh BAAK.
b. Mengisi FKM melalui SIJadKul.
c. Mengakses Jadwal Kuliah melalui SIJadKul.

\section{BAAK :}

a. Menerima DMD yang telah disahkan dari Waket 1.

b. Input DMD kedalam SIJadKul.

c. Menerima Data Ruangan dari Bag. Umum.

d. Input data ruangan ke dalam SIJadKul

e. Membuat Jadwal Kuliah menggunkan SIJadKul.

4. Bag. Umum :

Memberikan data ruangan ke BAAK.

\section{Mahasiswa :}

Melihat Jadwal Kuliah melalui SIJadKul.

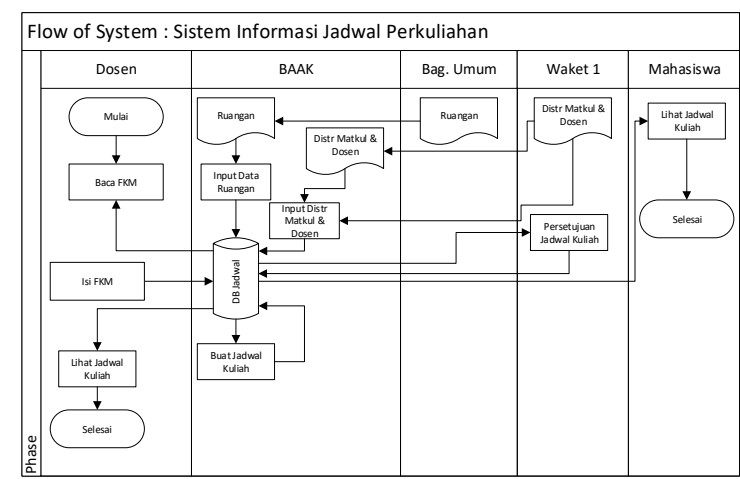

Gambar 5 Alur Sistem Jadwal Perkuliahan

\section{Keterangan :}

FKM : Formulir Kesediaan Mengajar

Distr MatKul \& Dosen : Distribusi Matakuliah dan Dosen

DBJadwal : database Jadwal kuliah dengan memiliki enam (6) tabel yaitu Tabel Dosen, Tabel Matakuliah, Tabel KM (Kesediaan Mengajar), Tabel DsrtMKDsn (Distribusi Matakuliah dan Dosen, Tabel Ruang, dan Tabel JadwalKuliah.

Diagram konteks (DK) merupakan penggambaran secara keseluruhan hubungan antara sistem dengan external entity, pada gambar diagram konteks di bawah ini system terhubung dengan empat (4) external entity yaitu: Wakil Ketua 1 (Waket 1), Bagian Umum (Bag. Umum), Dosen, dan Mahasiswa.

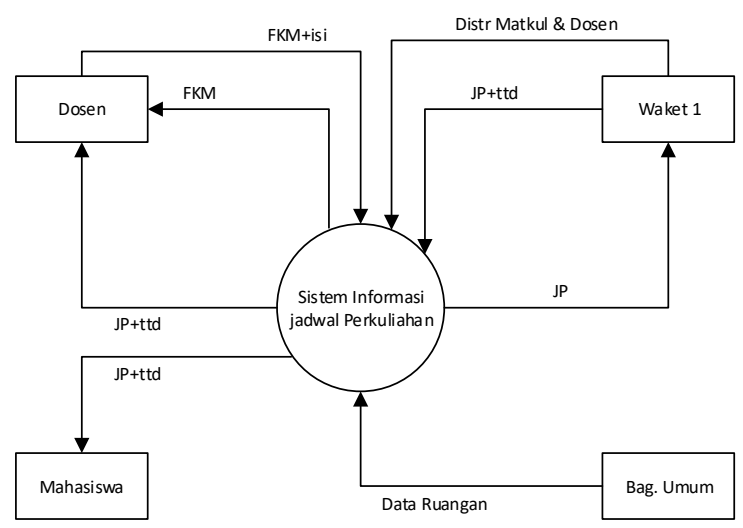

Gambar 6 Diagram Konteks Sistem Informasi Jadwal Perkuliahan

Keterangan :

FKM : Formulir Kesediaan Mengajar

FKM+isi : Formulir Kesediaan Mengajar yang sudah di isi oleh dosen

Distr MatKul \& Dosen : Distribusi Matakuliah dan Dosen

JP : Jadwal perkuliahan

JP+ttd : jadwal perkuliahan yang sudah disetujui oleh Waket1.

Berdasarkan DK diatas kemudian dibuatlah Data Flow Diagram Level 0/Overview yang menggambarkan arus data dari external entity ke proses dan arus data dari proses ke external entity, seperti gambar 6 dibawah ini. 


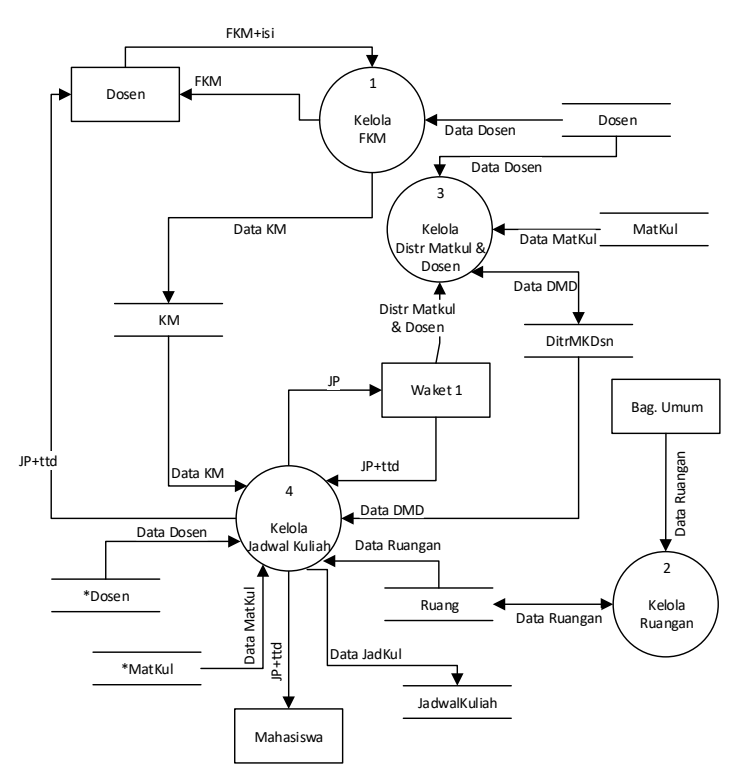

Gambar 7 DFD Level 0/Overview SIJadKul

Entity Relationship Diagram (ERD) adalah diagram yang menggambarkan model relasi antar entitas yang ada pada sistem.

ERD yang digambarkan yaitu relasi antar tabel pada database yang dibangun, dapat dilihat pada gambar dibawah ini.

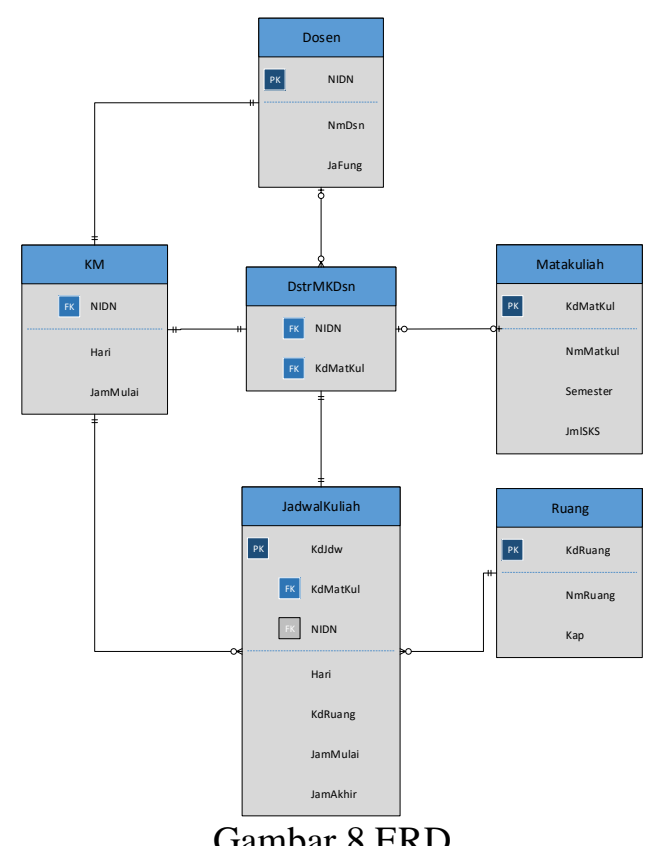

Rancangan Tabel yang terdiri dari empat (4) tabel, yang terdiri dari tabel Dosen, tabel Matakuliah, tabel Mengampu, tabel JadwalKuliah, seperti terlihat pada tabel-tabel dibawah ini.
1. Tabel Dosen

Tabel dosen digunakan untuk menyimpan data dosen yang mengajar. Jumlah field ada 4 field (Tabel 1), primery key (PK) dari tabel dosen adalah NIDN.

Tabel 1 Tabel Dosen

\begin{tabular}{|c|l|c|c|}
\hline No & $\begin{array}{c}\text { Nama } \\
\text { Field }\end{array}$ & Tipe & Size \\
\hline 1 & NIDN & Varchar & 10 \\
\hline 2 & NmDsn & Varchar & 30 \\
\hline 3 & Jafung & Varchar & 11 \\
\hline
\end{tabular}

2. Tabel Matakuliah

Tabel matakuliah ini akan menampung data matakuliah yang terdapat pada kurikulum di setiap program studi (Prodi). Tabel matakuliah ini memiliki 4 field dengan PK KdMatKul

Tabel 2 Tabel Matakuliah

\begin{tabular}{|c|l|c|c|}
\hline No & Nama Field & Tipe & Size \\
\hline 1 & KdMatkul & Varchar & 10 \\
\hline 2 & NmMatkul & Varchar & 50 \\
\hline 3 & Semester & Integer & 1 \\
\hline 4 & JmlSKS & Integer & 1 \\
\hline
\end{tabular}

3. Tabel Mengampu

Tabel pengampu merupakan tabel tentan data dosen yang akan mengajar pada semester berjalan yang memiliki dua (2) fields. Yang mempunyai relasi dengan tabel Dosen dan tabel Matakuliah.

Tabel 3 Tabel DstrMKDsn

\begin{tabular}{|c|l|c|c|}
\hline No & Nama Field & Tipe & Size \\
\hline 1 & NIDN & Varchar & 10 \\
\hline 2 & KdMatkul & Varchar & 10 \\
\hline
\end{tabular}

4. Tabel KM (Kesediaan Mengajar)

Tabel ini berisikan kesediaan dosen dalam mengajar berdasarkan distribusi mata kuliah dan dosen. Tabel ini hanya memiliki tiga (3) fields dengan PK NIDN.

Tabel 4 Tabel KM (Kesediaan Mengajar)

\begin{tabular}{|c|l|c|c|}
\hline No & Nama Field & Tipe & Size \\
\hline 1 & NIDN & Varchar & 10 \\
\hline 2 & Hari & Integer & 1 \\
\hline 3 & JamMulai & & \\
\hline
\end{tabular}

5. Tabel Ruang

Tabel ini merupakan tabel untuk identitas ruang serta kapasitas ruangan. Jumlah fields pada tabel ruang adalah tiga (3) fields. 
Tabel 5 Tabel DstrMKDsn

\begin{tabular}{|c|l|c|c|}
\hline No & \multicolumn{1}{|c|}{ Nama Field } & Tipe & Size \\
\hline 1 & KdRuang & Varchar & 4 \\
\hline 2 & NmRuang & Varchar & 6 \\
\hline 3 & Kap & integer & 3 \\
\hline
\end{tabular}

6. Tabel JadwalKuliah

Untuk tabel jadwalkuliah mempunyai relasi dengan tabel mengampu. Tabel JadwalKuliah terdiri atas enam (6) fields dengan PK KdJdw.

Tabel 6 Tabel JadwalKuliah

\begin{tabular}{|c|l|c|c|}
\hline No & Nama Field & Tipe & Size \\
\hline 1 & KdJdw & Varchar & 5 \\
\hline 2 & KdMatKul & Varchar & 10 \\
\hline 3 & Hari & Integer & 1 \\
\hline 4 & KdRuang & Varchar & 4 \\
\hline 5 & JamMulai & & \\
\hline 6 & JamAkhir & & \\
\hline
\end{tabular}

\section{Kesimpulan dan Saran}

\section{Kesimpulan}

Hasil penelitian dan analisis yang dilakukan

di STMIK Rosma maka dapat di ambil kesimpulan :

1. Untuk pengolahan data penjadwalan kuliah menggunakan sistem yang terkomputansi lebih baik dan efektif dibandingkan dengan sistem yang manual, walaupun sistem ini belum di terapkan di STMIK Rosma.

2. Dengan sistem yang dibuat maka proses penjadwalan kuliah dapat dilakukan dengan cepat.

3. Apabila ada perubahan jadwal kuliah info yang di sampaikan lebih cepat, karena bisa langsung di akses oleh dosen dan mahasiswa melalui web kampus.

4. Mahasiswa tidak perlu ke kampus untuk melihat jadwal perkuliahan, karena jadwal tersebut bisa diakses melalui web kampus asal komputer atau handphone mahasiswa terhubung ke jaringan internet.

\section{Saran} adalah :

Adapun saran yang di sampaikan peneliti

1. Penerapan sistem yang baru akan berjalan sesuai yang di inginkan apabila pihak yang terlibat di dalamnya dapat mendukung penerapan sistem baru.
2. Sesuai dengan perkembangan teknologi informasi, maka sistem informasi yang digunakan harus selalu di analisis apakah masih layak atau tidak, sehingga dapat di ketahui perlu tidaknya pengembangan sistem yang ada demi memenuhi kebutuhan sistem.

\section{Daftar Pustaka}

Darmadji, P. A. adelia. (2008). Pengembangan Sstem Informasi Penjadwalan Perkuliahan Elektronik berbasis Web dengan SMS Gateway. Universitas Indonesia.

Fachrurozi. (2011). Sistem Informasi Penjadwalan Matakuliah pada International programs fakultas sains dan teknologi UIN Syarif Hidayattullah. Repository UINJKT, 0111-10-97(05/08/2012).

http://repository.uinjkt.ac.id/ dspace/handle/123456789/198

Hartono, B. (2013). Sistem Informasi Manajemen Berbasis Komputer. Rineka Cipta.

Jogiyanto. (2010). Analisa dan Desain Sistem Informasi. In Yogyakarta: Andi (3rd ed.).

Maria, K. (2010). Analisis Dan Perancangan Sistem Informasi Penjadwalan Kuliah Pada STIE Muhammadiyah Pekalongan. November, 210.

Nurwarsito, H. (2009). Sistem Informasi Jadwal Perkuliahan dengan Metode Sistem Pakar. Eeccis, III(1), 57-61. http://jurnaleeccis.ub.ac.id/index.php/eeccis /article/view/131/127

Sommerville, I. (2011). Software Engineering (Rekayasa Perangkat Lunak). In Jakarta: Erlangga (6th ed.). Erlangga.

Sutanta, E. (2011). Basis Data dalam Konseptual. In Yogyakarta: Andi.

Wibisono, Y., Megasari, R., \& Kom, S. (2009). Pembangunan Sistem Penjadwalan Kuliah Di Program Studi Ilmu Komputer Dengan Graph Colouring. Tidak Dipublikasikan, 15.

Yaqub. (2012). Pengantar Sistem Informasi. Graha Ilmu.

Sommerville, Ian, Software Engineering (Rekayasa Perangkat Lunak). Jakarta: Erlangga, 2011. 